\title{
1 Two Distinct Patterns of Seasonal Variation of 2 Airborne Black Carbon over Tibetan Plateau
}

3 Mo Wang ${ }^{\text {a, *}, ~ B a i q i n g ~ X u ~}{ }^{\text {a, b }}$, Ninglian Wang ${ }^{\text {c, b }}$, Junji Cao ${ }^{\text {d, e }}$, Xuexi Tie ${ }^{\text {e, f }}$, Hailong 4 Wang $^{\mathrm{g}}$, Chongshu Zhu ${ }^{\mathrm{d}, \mathrm{e}}$, Wei Yang ${ }^{\mathrm{a}, \mathrm{b}}$,

$5{ }^{a}$ Key Laboratory of Tibetan Environment Changes and Land Surface Processes, Institute of 6 Tibetan Plateau Research, Chinese Academy of Sciences, Beijing 100101, China

$7 \quad{ }^{b}$ CAS Center for Excellence in Tibetan Plateau Earth Sciences, Beijing, China

$8{ }^{c}$ State Key Laboratory of Cryospheric Sciences, Cold and Arid Regions Environmental and

9 Engineering Research Institute, Chinese Academy of Sciences, Lanzhou, China

${ }^{d}$ Key Laboratory of Aerosol Chemistry and Physics, Institute of Earth Environment, Chinese 11 Academy of Sciences, Xi'an, China

$12{ }^{e}$ SKLLQG, Institute of Earth Environment, Chinese Academy of Sciences, Xi' an, China

$1{ }^{f}$ Center for Excellence in Urban Atmospheric Environment, Institute of Urban Environment,

14 Chinese Academy of Sciences, Xiamen 361021, China

$15{ }^{g}$ Atmospheric Sciences and Global Change Division, Pacific Northwest National Laboratory 16 (PNNL), Richland, WA 99352, USA

* Corresponding author. Institute of Tibetan Plateau Research, Chinese Academy of Science, 


\section{ABSTRACT}

Airborne black carbon (BC) mass concentrations were measured from November 2012 to June 2013 at Ranwu and Beiluhe, located in the southeastern and central Tibetan Plateau, respectively. Monthly mean $\mathrm{BC}$ concentrations show a winter (November-February) high (413.2 $\mathrm{ng} \mathrm{m}^{-3}$ ) and spring (March-June) low (139.1 ng $\mathrm{m}^{-3}$ ) at Ranwu, but in contrast a winter low and spring high at Beiluhe (204.8 and $621.6 \mathrm{ng} \mathrm{m}^{-3}$, respectively). By examining the meteorological conditions at various scales, we found that the monthly variation of airborne $\mathrm{BC}$ over the southeastern Tibetan Plateau (TP) was highly influenced by regional precipitation and over the hinterland by winds. Local precipitation at both sites showed little impact on the seasonal variation of airborne $\mathrm{BC}$ concentrations. Potential $\mathrm{BC}$ source regions are identified using air mass backward trajectory analysis. At Ranwu, BC was dominated by the air masses from the northeastern India and Bangladesh in both winter and spring, whereas at Beiluhe it was largely contributed by air masses from the south slope of Himalayas in winter, and from the arid region in the north of the TP in spring. The winter and spring seasonal peak of BC in the southern TP is largely contributed by emissions from South Asia, and this seasonal variation is heavily influenced by the regional monsoon. In the northern $\mathrm{TP}, \mathrm{BC}$ had high concentrations during spring and summer seasons, which is very likely associated with more efficient transport of BC over the arid regions on the north of Tibetan Plateau and in Central Asia. Airborne BC concentrations at the Ranwu sampling site showed a significant diurnal cycle with a peak shortly after sunrise followed by a decrease before noon in both winter and spring, likely shaped by local human activities and the diurnal variation of wind speed. At the Beiluhe sampling site, the diurnal variation of $\mathrm{BC}$ is different and less distinct.

Keywords. Black carbon; Aerosol; Tibetan Plateau; Seasonal variation; Transport

\section{Introduction}

The Tibetan Plateau (TP) and surrounding mountains have large ice masses and an expanded area of seasonal/permanent snow cover, which ensure fresh-water 
supplies to major rivers in Asia, and presents the most sensitive and visible indicator of climate change with its unique location for complex interactions among the atmosphere, hydrosphere, and cryosphere (Richardson and Reynolds, 2000; Yao et al., 2004; Xu et al., 2009a; Qian et al., 2011). It was observed that glaciers on the TP have been retreating continuously, resulting in a negative glacial mass balance in recent decades (Yao et al., 2004). The shrinkage of glacier over the past 30 years generally present decreases from Himalayas to the continental interior and is the least in the eastern Pamir and it is attributed by the changes of precipitation pattern driven by atmospheric circulation (Yao et al., 2012). Moreover, the increase in black carbon (BC) together with other types of light-absorbing particles, including brown carbon (i.e., light-absorbing organic carbon) and dust, has been identified as another contributor to the accelerated glacier melt due to the absorption-induced heating in both the atmosphere and snowpack (Hansen and Nazarenko, 2004; Flanner et al., 2007; Ramanathan et al., 2007b; Ramanathan and Carmichael, 2008; Xu et al., 2009a; Kopacz et al., 2011; Qian et al., 2011; Chung et al., 2012; Hadley and Kirchstetter, 2012; Qian et al., 2014). For example, Ramanathan et al. (2007a, 2007b) have suggested that the large amount of $\mathrm{BC}$ over South Asia, which contributes to atmospheric heating at high elevation (3-5 $\mathrm{km}$ a.s.l.) by absorbing solar radiation, is one of major causes for the Himalayan-Hindu-Kush glacier ablation. On the other hand, $\mathrm{BC}$ deposited in snow has been proved to reduce snow albedo, speed up snow aging and accelerate snowpack melt through positive feedback mechanisms (Warren and Wiscombe, 1980; Hansen and Nazarenko, 2004; Flanner et al., 2007; Ming et al., 2009; Xu et al., 2009a; Yang et al., 2015). Consequently airborne and in-snow BC particles over the TP have impacts on the fresh water supplies to a large population.

The TP adjoins several important BC emission regions, including South and East Asia with very high population density and significant anthropogenic activities, Central Asia with an extensive arid/semi-arid region, and Taklimakan and Qaidam Basin deserts on the north. Several previous studies have shown that emissions from South Asia can be transported through the Himalayas to the central TP (Kopacz et al., 
2011; Cong et al., 2015; Lüthi et al., 2015; Zhang et al., 2015), and the emissions from Europe and Central Asia are the primary contributor to the BC deposition on Pamirs (Wang et al., 2015b). Moreover, it has been indicated that the TP also receives BC and dust from Northern Africa (Wu et al., 2010; Lu et al., 2012; Zhang et al., 2015).

The TP airborne BC concentration has large spatiotemporal variations, depending on emissions and atmospheric circulation. Observed airborne BC in the Himalayas shows the highest values in spring, which are closely related to the high pollutant-loaded brown cloud over South Asia and the increased convective uplifts in spring (Hyvärinen et al., 2009; Babu et al., 2011; Nair et al., 2013; Zhao et al., 2013), whereas in the Pamirs and Qilian Shan BC peaks during summer, which is associated with the more efficient transport from the planetary boundary layer in Central Asia and northwestern China (e.g., Wu et al., 2008; Cao et al., 2009; Zhao et al., 2012; Wang et al., 2015b).

Real-time observation airborne of $\mathrm{BC}$ is especially important not only in the identification of $\mathrm{BC}$ variation and its source apportionment, but also for understanding the contribution of $\mathrm{BC}$ to the spatiotemporal changes of glacier/snowpack and, consequently, evaluating the climate effects of BC. However, measurements of airborne $\mathrm{BC}$ concentration in the remote $\mathrm{TP}$, especially real-time observations, are sparse and limited, and information on $\mathrm{BC}$ seasonal variation is lacking. In the present study, we use two sets of 7-wavelength Aethalometers (AE-31) to monitor the airborne BC concentrations in the southeastern and central TP from November 2012 to June 2013. The measurements are analyzed to examine seasonal and diurnal variations of $\mathrm{BC}$ at the two locations. To the best of our knowledge, the airborne $\mathrm{BC}$ measurements presented here in this study are the first real-time high-resolution observation in these two regions of TP.

\section{Methodologies}

\subsection{Research regions}




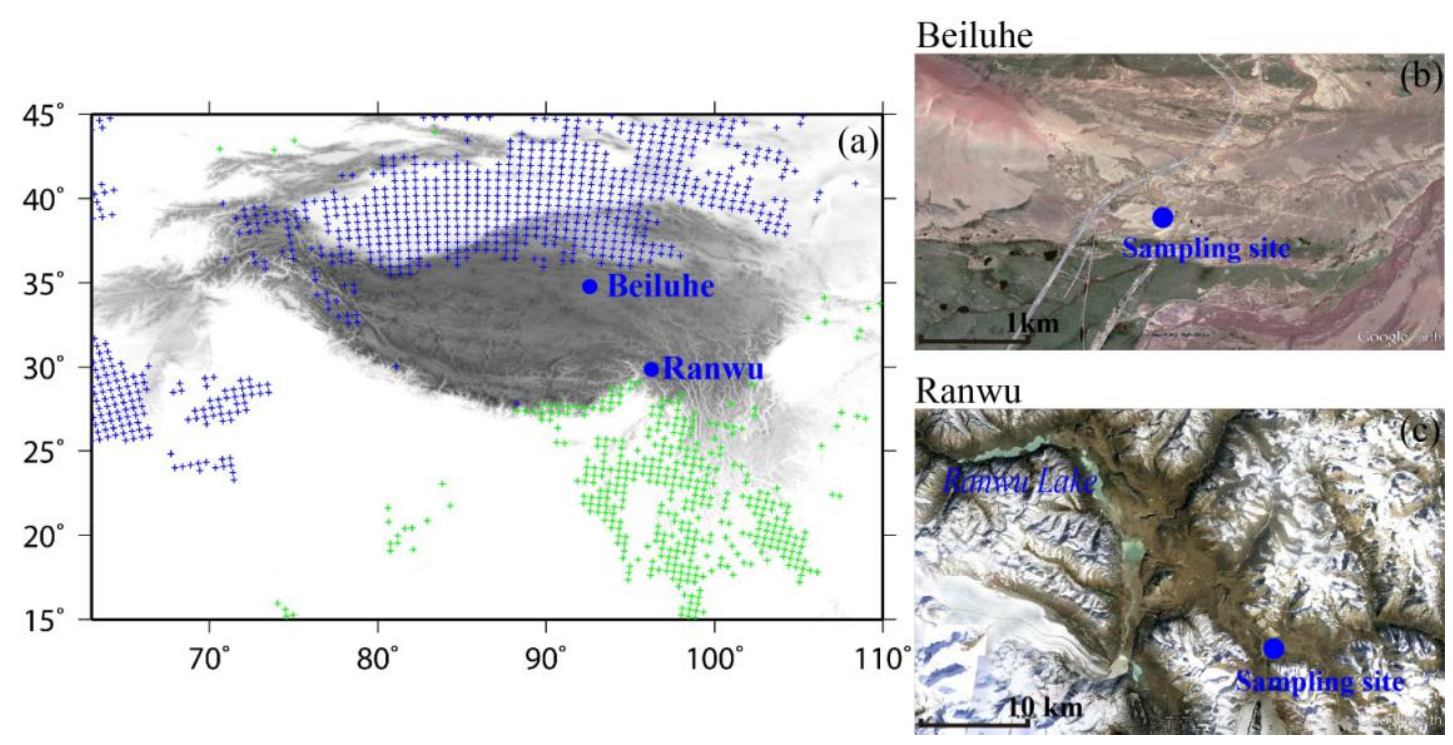

109

Figure 1: Locations of the sampling sites, Beiluhe and Ranwu (a). Arid regions are stippled in blue and forests in green (USDA, 1999; Lawrence and Chase, 2007; Ji et al., 2016). Topography maps for the Beiluhe and Ranwu sampling sites are plotted in (b) and (c), respectively.

The topography of southeastern TP is characterized by the steep Brahmaputra Valley on the southwest, through which abundant water vapor nurtures thick vegetations (Ye and Gao, 1979) (Fig. 1a, stippled in green). Based on about 40 years of observations at Zayu and Bomi meteorological stations, which are about $90 \mathrm{~km}$ away to the southeast and $130 \mathrm{~km}$ to the northwest of the sampling location, respectively, the annual precipitation is over $600 \mathrm{~mm}$ and the precipitation season lasts from March to October (Fig. 2, the top plot). With extensive forest cover due to significant moisture and very small amount of residents, local crustal particles and anthropogenic emissions are both minimum and the airborne pollutant in this region is mainly dominated by long-range transport from upwind regions (Cao et al., 2010; Zhao et al., 2013). Previous studies have elucidated that under the control of westerlies in winter and Indian monsoon in summer the majority of aerosols in the 
southeastern TP is transported from South Asia (Xu et al., 2009b; Zhao et al., 2013; Wang et al., 2015a). Zhang et al. (2015) found that emissions from south Asia contribute to $74 \%$ of annual mean airborne $\mathrm{BC}$ in the southeastern TP. The sampling site of southeastern TP in the present study is located at Ranwu $\left(29.32^{\circ} \mathrm{N}, 96.96^{\circ} \mathrm{E}\right.$, $4600 \mathrm{~m}$ a.s.1.), in a valley surrounded by mountains (Fig. 1c). BC observations are performed from 23 November, 2012, to 22 June, 2013.

The other sampling site is located at the Beiluhe Meteorological Station $\left(34.85^{\circ} \mathrm{N}, 92.94^{\circ} \mathrm{E}, 4600 \mathrm{~m}\right.$ a.s.1.), in between the Tanggula and Kunlun Mountains at the east of Kekexili (also known as Hoh Xil), which is mostly uninhabited region on the TP (Fig. 1b). To the east, with sparse population, grasslands are widely distributed and provide headwater for Yangtze and Yellow Rivers. To the west, Ngari has the lowest population density of any prefecture in the TP. The Qinghai-Tibet railway and the Qinghai-Tibet highway go through each side of the sampling site. Due to the transport of dry air masses from the arid/semi-arid Central Asia by the year-around westerlies, the climate in this region is characterized by a long dry season (September -May). Seasonal rainfalls in summer (June-September) are most likely brought by the moist air mass transported from South Asia (Yao et al., 2013). Observations of precipitation from 2003-2015 at the Meteorological Station of Permafrost Study Station at Beiluhe showed an annual mean of $\sim 350 \mathrm{~mm}$ with $86 \%$ of the precipitation occurred during June to September (Fig. 2, the bottom plot). The AE-31 located at this Meteorological Station operated from 27 November, 2012, to 19 June, 2013.

\subsection{BC Measurements}

The Aethalometer provides continuous estimates of $\mathrm{BC}$ mass at seven fixed wavelengths (i.e., 370, 470, 520, 590, 660, 880 and $950 \mathrm{~nm}$ ) in real time. BC mass was obtained by monitoring the attenuation of a beam of light transmitted through the aerosols collected on a quartz fiber filter at $880 \mathrm{~nm}$. The attenuation coefficient of the Aethalometer used herein for the calculation of $\mathrm{BC}$ mass was $16.6 \mathrm{~m}^{2} \mathrm{~g}^{-1}$ as recommended by the manufacturer (Hansen, 2005). This method has shown good 
agreement with other analytic techniques (Allen et al., 1999; Jeong et al., 2004) and has been widely used (e.g., Babu et al., 2011; Nair et al., 2013; Hyvärinen et al., 2009). The principle of the method is described in detail in Hansen et al. (1982). In the present study, both Aethalometers sampled through an inlet without any cut on particle sizes. The instruments were operating in an automated mode at a flow rate of 4.0 LPM (liter per minute) at Ranwu and 5.0 LPM at Beiluhe. BC and other light absorbing particulate concentrations were obtained every 5 minutes. Note that the power to run the Aethalometer located in Ranwu was supplied by a solar power system, so BC measurements at the Ranwu sampling site were unavailable sometimes especially during cloudy and rainy days, which occurred very often in spring and early summer of the study period here.

\subsection{Data Processing}

Based on the meteorological observations at the sampling sites, the mean surface pressure and temperature for Ranwu are $583 \mathrm{hPa}$ and $270.6 \mathrm{~K}$ during the sampling period, and $578 \mathrm{hPa}$ and $268 \mathrm{~K}$, respectively, for the Beiluhe site. The ambient BC concentrations are calculated using the following equation (Babu et al., 2011):

$$
M_{B C}=M_{B C}^{*} \times\left[\frac{P_{0} T}{P T_{0}}\right]
$$

where $M_{B C}^{*}$ represents the instrument measured raw mass concentration at ambient conditions, $P_{0}$ and $P$ are the standard and ambient pressure and $T_{0}$ and $T$ are the corresponding temperatures.

The Aethalometers were deployed in a fairly pristine environment, but there might be some artifacts associated with favorable conditions, especially for the sampling site of Beiluhe, as the instrument was set up at the Meteorological Station between the Qinghai-Tibet highway and a railway (Fig. 1b). A few large sudden increases (e.g., two to three orders of magnitude) that lasted 5-20 minutes occurred occasionally. Such artifacts can cause a high bias in the BC concentrations of the remote $\mathrm{TP}$ that are normally very low. To check the $\mathrm{BC}$ measurement data for such 
180 biases, a frequency distribution, based on individual 5-min BC measurements, has 181 been used separately for winter (November - Feburary) and spring (March - June), as 182 the ambient BC concentrations vary largely with seasons (cf. Sect. 3.1). The 183 distributions of the frequency of occurrence of $M_{B C}$ are greatly skewed (Fig. S1). At 184 the Ranwu sampling site, BC concentrations (measured at 880nm wavelength) are 185 mostly (97.5\%) below $1000 \mathrm{ng} \mathrm{m}^{-3}$ in winter and below $600 \mathrm{ng} \mathrm{m}^{-3}$ in spring. At 186 Beiluhe the $\mathrm{BC}$ concentrations are mostly below $1400 \mathrm{ng} \mathrm{m}^{-3}$ in winter and below $1874000 \mathrm{ng} \mathrm{m}^{-3}$ in spring. In the present study, high BC concentrations in the top $2.5 \%$ 188 are excluded from the analysis if they lasted for less than 25 minutes (i.e., 5 189 consecutive samples).

\subsection{Meteorological Data and Satellite Products}

The precipitation data in the research regions are from meteorological data 192 collected at national ground stations (Valipour, 2014; Valipour, 2015; Valipour and 193 Eslamian, 2015). The monthly mean precipitation at Zaya $\left(28.39^{\circ} \mathrm{N}, 97.28^{\circ} \mathrm{E}, 2328 \mathrm{~m}\right.$ 194 a.s.l.) are calculated using datasets from 1969 to 2013 , at Bomi $\left(29.52^{\circ} \mathrm{N}, 95.46^{\circ} \mathrm{E}\right.$, $1952736 \mathrm{~m}$ a.s.1.) from 1954-2013, at Linzhi (29.40 $\mathrm{N}, 94.20^{\circ} \mathrm{E}, 2992 \mathrm{~m}$ a.s.1.) from 1954-2013, and at Wudaoliang $\left(35.13^{\circ} \mathrm{N}, 93.05^{\circ} \mathrm{E}, 4612 \mathrm{~m}\right.$ a.s.1.) from 1957-2014.

197 Meteorological parameters at the Ranwu and Beiluhe sampling sites, i.e., monthly 198 pressure, monthly temperature, daily precipitation and half-hourly winds (direction 199 and speed), are obtained from automatic weather stations (AWSs). spring (March 2013-June 2013) seasons at $500 \mathrm{hPa}$ and surface are generated from the NCEP/NCAR reanalysis dataset, which has a horizontal grid spacing of $2.5^{\circ} \times 2.5^{\circ}$ and 17 vertical levels. The daily mean aerosol optical depth (AOD) spatial distribution for winter and spring are generated using daily AOD at $550 \mathrm{~nm}$ from the

Deep Blue dataset (MODIS-Aqua) with a spatial resolution of $1^{\circ} \times 1^{\circ}$ (http://giovanni.gsfc.nasa.gov/giovanni/). 


\subsection{Monthly Variations of BC over the TP}

The mean concentration of airborne $\mathrm{BC}$ during the observation period at Ranwu

210 is $139.1 \mathrm{ng} \mathrm{m}^{-3}$, and $413.2 \mathrm{ng} \mathrm{m}^{-3}$ at Beiluhe. The monthly concentrations of $\mathrm{BC}$ at 211 Ranwu and Beiluhe are calculated and shown in Fig. 2, along with the monthly BC 212 concentrations at Lulang sampling site $\left(94.44^{\circ} \mathrm{E}, 29.46^{\circ} \mathrm{N}, 3300 \mathrm{~m}\right.$ a.s.l.) that is about $213250 \mathrm{~km}$ west of the Ranwu sampling site (Zhao et al., 2013). The BC concentrations 214 at Ranwu are evidently higher in winter (374.4 $\mathrm{ng} \mathrm{m}^{-3}$ on average) than in spring $215\left(103.8 \mathrm{ng} \mathrm{m}^{-3}\right)$. The monthly variation of BC at Ranwu is similar to the variation of 216 BC at Lulang, although the latter peaks in March whereas the former in February (Fig. 217 2, middle). However, BC at Beiluhe in the central TP shows higher monthly mean 218 concentrations in spring $\left(621.6 \mathrm{ng} \mathrm{m}^{-3}\right)$ than in winter $\left(204.8 \mathrm{ng} \mathrm{m}^{-3}\right)$. 

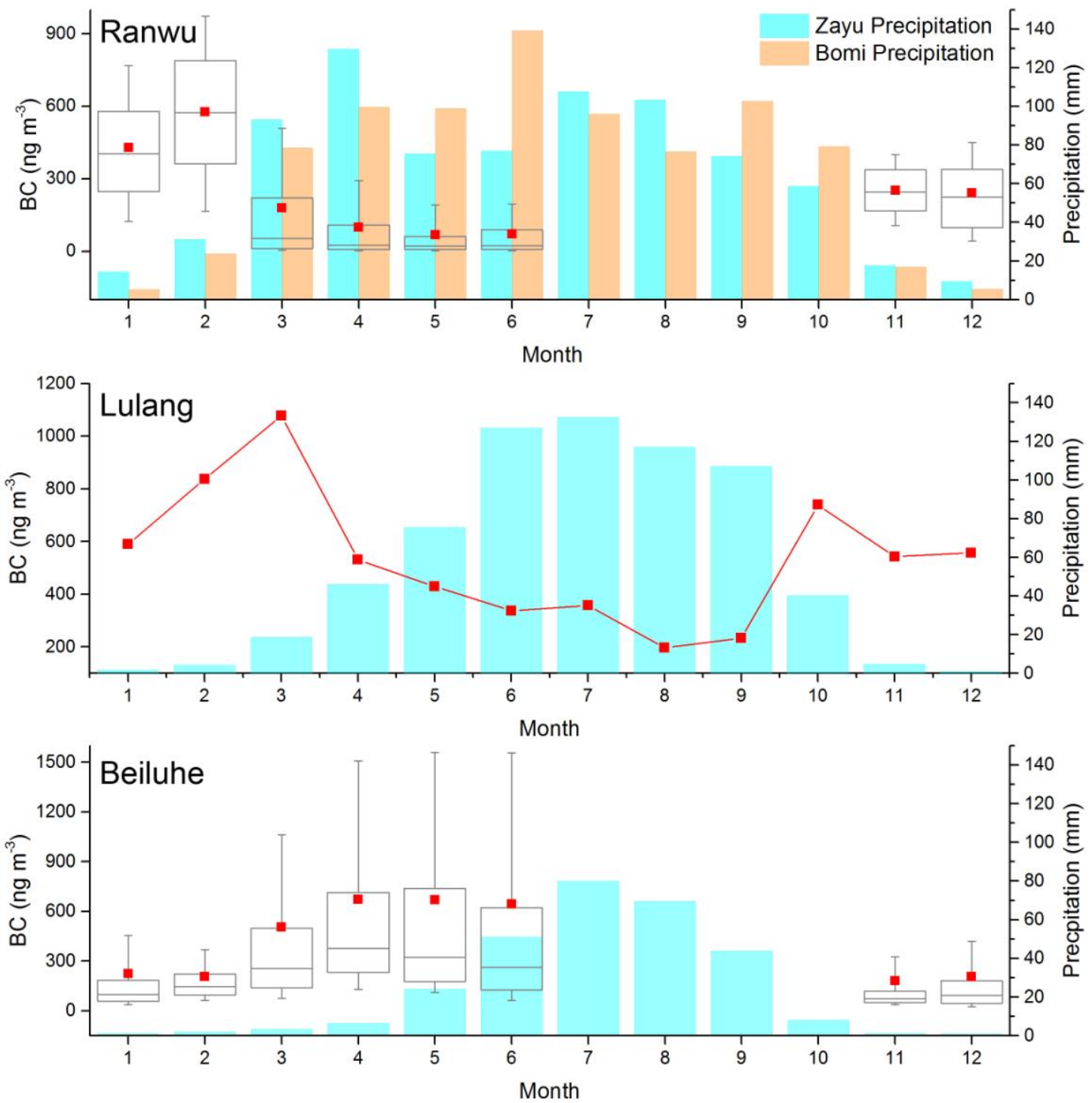

Figure 2 Monthly mean BC concentrations (gray boxes and whiskers with red square symbols) at Ranwu (top) and Beiluhe (bottom), along with BC concentrations at Lulang (middle, red line with square symbols) from Zhao et al. (2013). The 25th, 50th, and 75th percentiles are marked with the box, and the 10th and 90th percentiles marked with whiskers. The red square symbols denote mean values. Monthly total precipitations are shown in cyan and orange bars.

The seasonal pattern of airborne BC concentrations over the TP is likely due to the variations of emissions and/or meteorological conditions that determine transport pathways and removals during the transport. We first look at the meteorological conditions on the regional and local scales to understand the cause of the seasonal 
patterns of airborne $\mathrm{BC}$ concentrations.

The monthly mean precipitation (Fig. 2) from multi-decade data shows distinguished seasonal variations. Mean precipitation at the Ranwu sampling site is based on climatological data collected at the Zayu and Bomi meteorological stations. Note that we use multi-decade precipitation data but not the precipitation data for the BC sampling period in the present study (Fig. S2) because the climatological data can better characterize the seasonal pattern of precipitation on a regional scale. Monthly precipitation amounts at the two stations show similar seasonal variations (Fig. 2, top) with a remarkably high rainfall from March to October $(\sim 90$ and $\sim 100 \mathrm{~mm} / \mathrm{month}$ at Zayu and for Bomi, respectively). Precipitation for the Lulang sampling site is based on observations at the Linzhi meteorological station $60 \mathrm{~km}$ away, which shows a rapid increase from March to June and then stayed at a high value until October $(\sim 120$ $\mathrm{mm} / \mathrm{month}$ averaged from June to September) (Fig. 2, middle). The regional precipitation tends to be negatively correlated with monthly $\mathrm{BC}$ in the southeastern Tibetan Plateau. The monthly airborne BC concentration is very likely associated with wet deposition determined by the regional precipitation. The mean wind fields for winter and spring at the surface and $500 \mathrm{hPa}$ from the NCEP/NCAR reanalysis data (http://www.esrl.noaa.gov/psd/data) show the prevailing winds were from the southwest in both winter and spring (Fig. 3), which indicates the importance of emissions from upwind source regions (i.e., eastern India and Bangladesh) and the key role of seasonal precipitation in shaping the seasonal pattern of airborne BC concentrations in the southeastern TP. In addition, the higher mean AOD (Fig. 3) over eastern India and Bangladesh in winter suggests larger aerosol loading than in spring. Although this does not mean $\mathrm{BC}$ burden over this region is higher in winter, previous studies in northern India, do show higher BC concentrations in winter (e.g., Beegum et al., 2009; Tiwari, et al., 2009; Pathak et al., 2010). The potentially higher wintertime $\mathrm{BC}$ in the upwind region likely contributes to the seasonal variation of $\mathrm{BC}$ over the southeastern TP. 
(a) Winter, $500 \mathrm{hPa}$

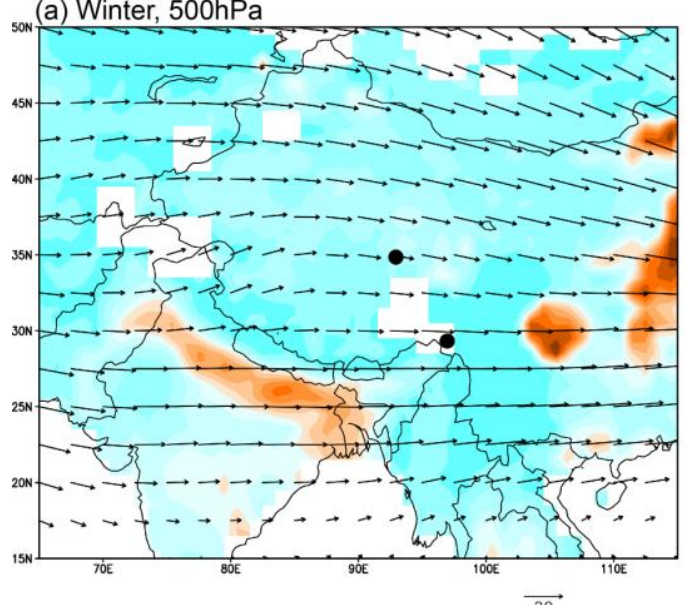

(c) Spring, $500 \mathrm{hPa}$

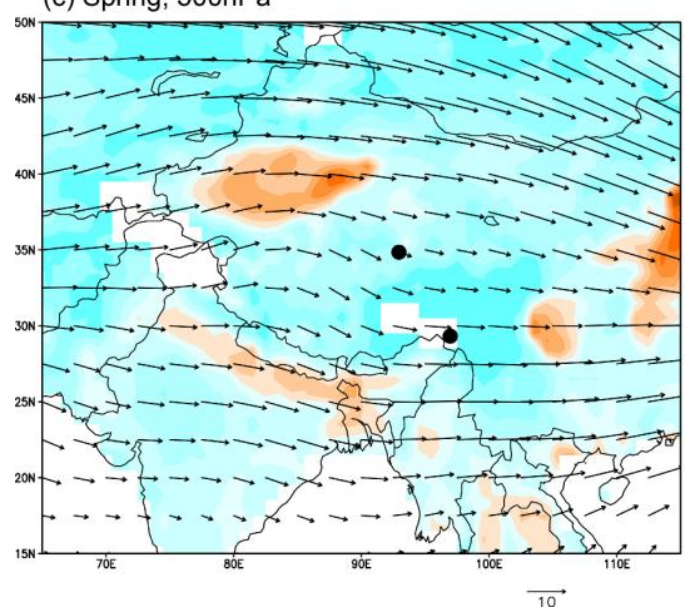

(b) Winter, surface

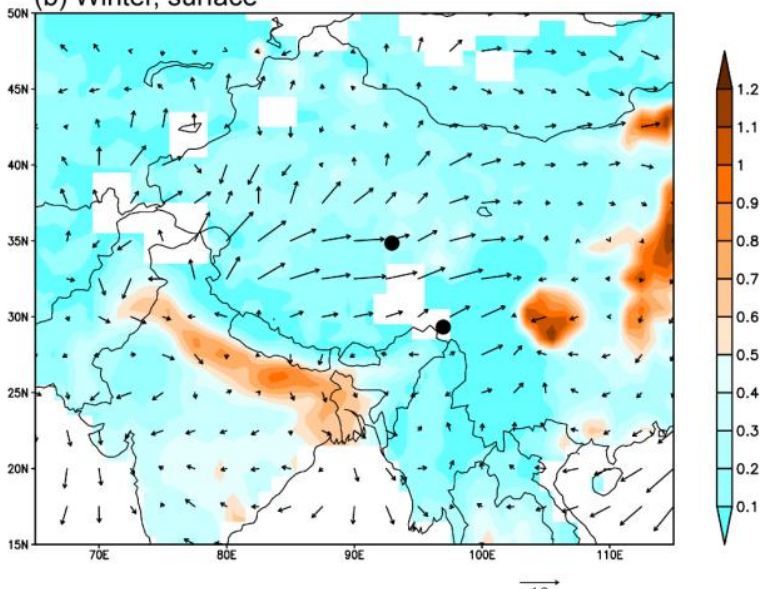

(d) Spring, surface

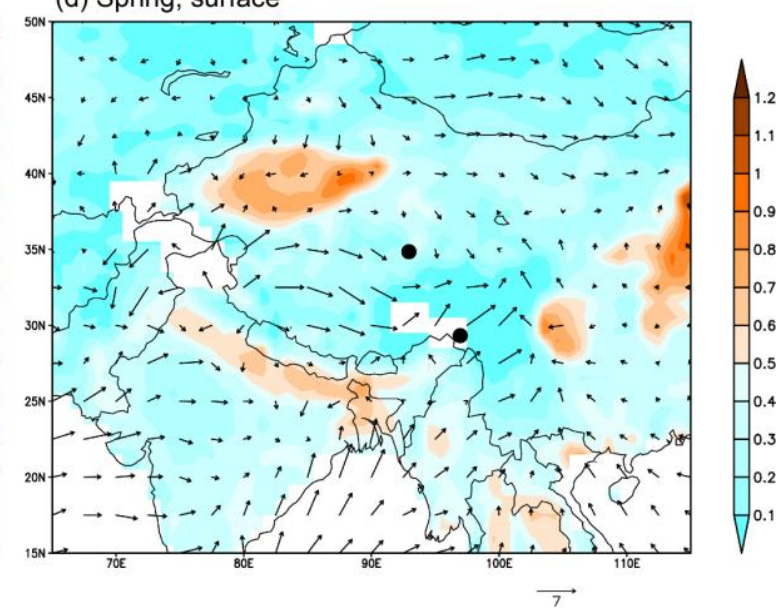

Figure 3 Mean wind vectors (denoted by arrows) at $500 \mathrm{hPa}(\mathrm{a}, \mathrm{c})$ and the surface (b, d) during the winter (November 2012-February 2013) and spring (March 2013 - June 2013) of the observation period based on NCEP/NCAR reanalysis data. The black dots mark the sampling sites at Ranwu and Beiluhe. The background colors show mean aerosol optical depth (AOD) at $550 \mathrm{~nm}$ to identify the spatial distribution of major emission regions.

At the Beiluhe sampling site precipitation in winter is very low, when the BC concentration is also relatively low (Fig. 2, bottom). The monthly precipitation increases during spring (March to June), reaching the maximum value in July, and then decreases from August to November. The monthly BC concentration rises when precipitation increases in spring. Thus, unlike the southeastern Tibetan Plateau, BC over the hinterland TP is not determined by the local precipitation. The wind fields in Fig. 3 suggest that air masses at $500 \mathrm{hPa}$ level are generally from the west in both 
winter and spring, whereas at the surface air masses are dominantly from the southwestern TP in winter and north-northwest in spring. The higher AOD over the Taklimakan Desert on the north of TP in spring suggests a large contribution by the increased emissions of mineral dust particles. The higher concentration of BC is very likely contributed by a more efficient transport or less removal of $\mathrm{BC}$ from the Taklimakan Desert and surrounding area. The particles from the hyper-arid Qaidam Basin may also contribute to high BC concentrations in spring, as it is located upwind of the Beiluhe sampling site.

Furthermore, high-frequency precipitation and wind direction measurements at each sampling site are also investigated. Daily precipitation amount, along with the daily mean $\mathrm{BC}$ concentrations, and wind direction frequency distributions in winter and spring are plotted in Fig. 4. There is no apparent relationship between BC concentrations and the daily precipitations at either Ranwu or Beiluhe; the correlation is very weak $\left(\mathrm{r}^{2}=0.06\right.$ for sampling days and 0.07 for raining days at Ranwu, and 0.04 and 0.08 respectively at Beiluhe). The one-way analysis of variance shows no difference in $\mathrm{BC}$ concentration between the days with and without precipitation (at the 0.05 significance level) at both Ranwu and Beiluhe. It probably indicates that the local precipitation cannot significantly change the concentration of airborne $\mathrm{BC}$ at both sites. The wind direction frequencies at the Ranwu sampling site show dominant west and northwest winds in both winter and spring seasons (Fig. 4, top), which is highly associated with the local topography (Fig. 1c). The prevailing winds favor a steady transport of air through the valley to the Ranwu sampling site. At the Beiluhe sampling site, winds in winter are predominantly from the west and northwest, while in spring a substantial number of counts are the north-east quadrant (Fig. 4, bottom). This is consistent with the mean wind fields at the surface (Fig. 3). According to the time series of half-hourly wind direction/speed and 5-minute BC concentrations (Fig. $\mathrm{S} 3$ ), the high BC concentrations at Beiluhe are very likely associated with the winds from northwest-east (shown in red arrows). 

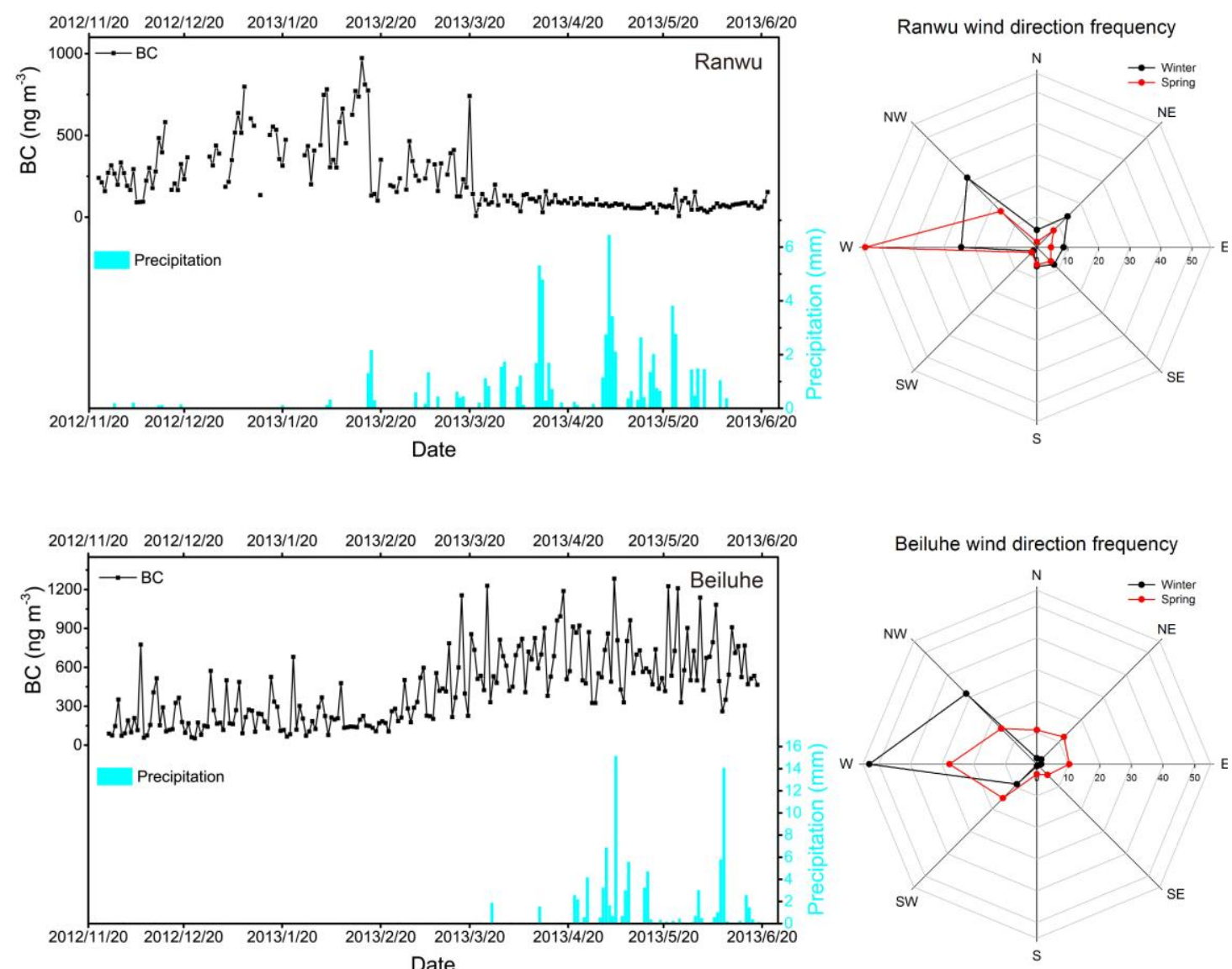

Figure 4 Time series of 5-min BC concentrations (black lines) and daily precipitation

The seasonal variation of airborne $\mathrm{BC}$ is important, as it determines the regional radiative impacts of $\mathrm{BC}$. Seasonal variations of $\mathrm{BC}$ at various locations over Tibetan Plateau from previous studies in the literature (Tang et al., 1999; Gao et al., 2007; Cao et al., 2009; Hyvärinen et al., 2009; Li et al., 2010; Ming et al., 2010; Ram et al., 2010; Zhao et al., 2012; Nair et al., 2013; Zhao et al., 2013) are summarized in Fig. 5. Note that BC concentrations at the different sites over the entire TP may not be comparable as the measurement methods vary from site to site. Here we only focus on the spatial variation of the seasonal pattern of BC concentrations. Generally speaking, BC in the southern Tibetan Plateau (e.g., Mt. Saraswati, Kullu, Manora Peak, 
and spring seasons, except that BC observed at Nam Co appeared to have a peak in July (Ming et al., 2010) probably because of missing observations in spring. Also note that airborne BC observed at Lhasa (Gao et al., 2007) is substantially higher than at the other southeast TP sites because of emissions from local domestic heating, even though it agrees well with the other sites in terms of the seasonal pattern. In the northern TP (e.g., Muztagh Ata, Qilian Shan, Waliguan and Beiluhe), airborne BC concentrations peaked in spring and summer seasons, with an exception in the Taklimakan Desert where BC had higher concentrations in winter among the months having observations (Li et al., 2010).

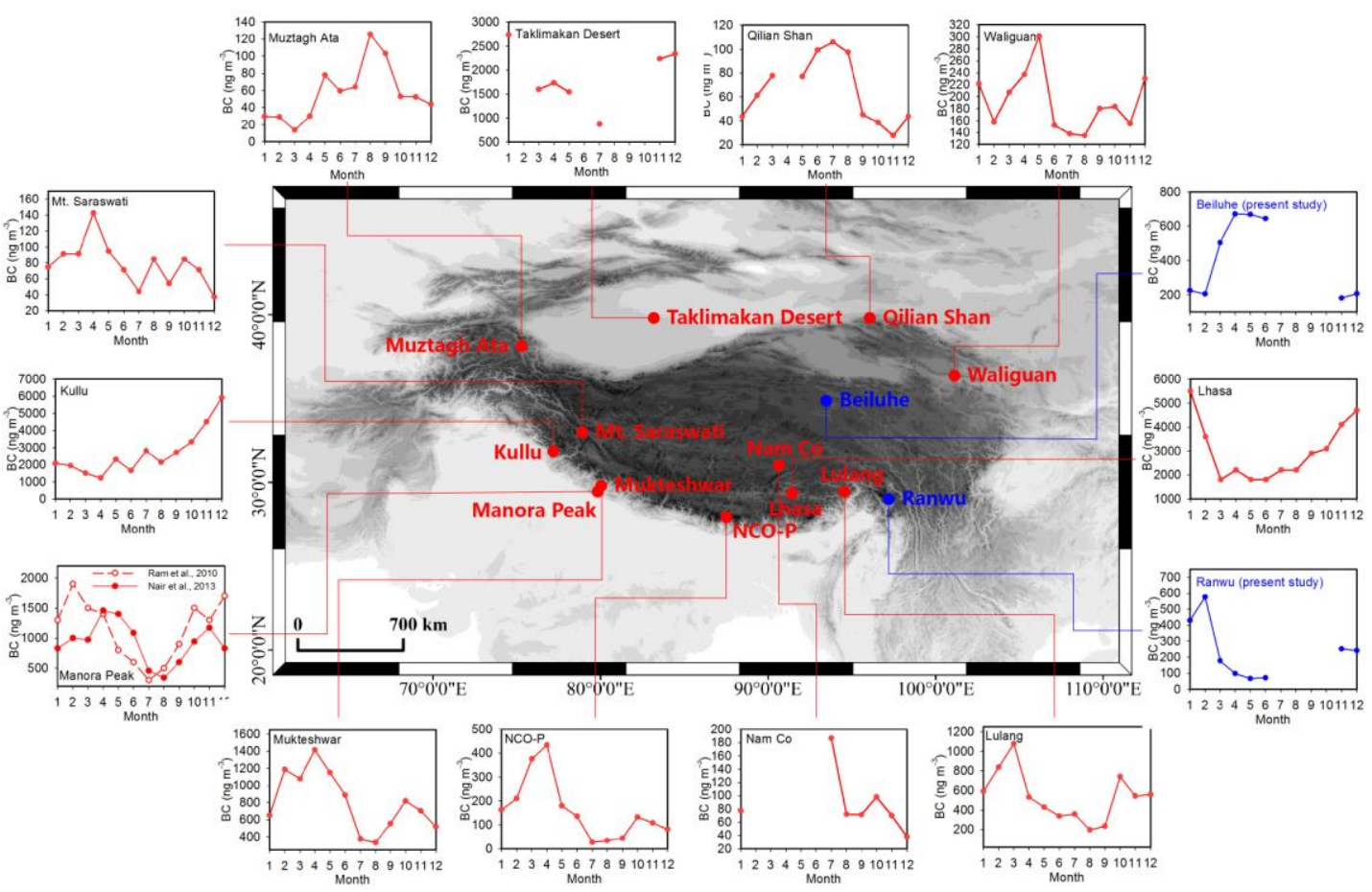

Figure 5 Spatiotemporal BC concentrations (ng m-3) measured at 14 sampling sites over Tibetan Plateau based on the observations described in this study (in blue) and others (in red) from Cao et al. (2010), Li et al. (2010), Zhao et al. (2012), Tang et al. (1999), Gao et al. (2007), Zhao et al. (2013), Ming et al. (2010), Nair et al. (2013), Hyvärinen et al. (2009), Ram et al. (2010), and Babu et al. (2011).

The seasonal pattern of airborne BC concentrations over TP predominately 
varies with atmospheric circulations, the emission sources on the upwind side, and/or precipitation along the transport pathway. The southern Tibetan Plateau is largely contributed by the emissions from South Asia transported by Indian monsoons and the south branch of westerlies alternatively. The increased $\mathrm{BC}$ over this region in winter and spring is highly related to the buildup of pollutants in the dry season over South Asia. In addition, the seasonal variation of precipitation plays an important role in shaping seasonal patterns of airborne $\mathrm{BC}$ in this region. In contrast, the northern Tibetan Plateau is controlled by the westerlies all year round, and the airborne BC is dominated by the transport from the arid and semi-arid region on the north TP and Central Asia (Fig. 1, blue stippling). With a weak influence of precipitation on BC wet deposition, the high $\mathrm{BC}$ concentration is mainly due to more efficient transport of $\mathrm{BC}$ particles from arid and semi-arid regions on the north TP and Central Asia in spring and summer. Our source attributions here are also consistent with the modeling study of Zhang et al. (2015), in which a BC emissions tagging technique employed in a global climate model was used to identify sources of BC at different locations and seasons in TP. They found that BC over the Himalayas and southeast TP in both winter and spring seasons originates predominantly from south Asia (mostly smoke sources). South Asia has less contribution to BC in central and northeast TP, especially in spring and summer, where and when emissions from the north and east become more important.

\subsection{Diurnal variations of $\mathrm{BC}$}

Diurnal variations and their seasonality are important in understanding the influences of local human activities and the effects of local meteorology and atmospheric boundary layer dynamics on BC transport/dispersion. The hourly mean $\mathrm{BC}$ concentrations at Ranwu and Beiluhe during winter and spring are shown in Fig. 6.

$\mathrm{BC}$ at Ranwu shows a discernable diurnal cycle in winter with a peak concentration occurring soon after sunrise and a rapid decrease before solar noon. The 
$\mathrm{BC}$ concentrations remain flat during the nighttime, and then reach a minimum before sunrise. The diurnal pattern featured with a peak shortly after sunrise and a decrease before noon is also observed in spring, although the amplitude is weaker. Note that BC observations between midnight and early morning are mostly unavailable, especially for the spring cloudy/rainy season when the solar electric system cannot be fully charged in the daytime. The similar magnitude of increase in both winter and spring soon after sunrise at the Ranwu site is very likely related to emissions from residential wood burning for cooking and heating in the surrounding area and the stable nocturnal boundary layer (Fig. S4). Solar heating to the surface and the increased wind speed in the late morning strengthens the mixing and dispersion of aerosol particles emitted from the local sources, causing a significant dilution of BC near the site. When solar heating and the winds peak in the afternoon, BC concentration reaches the diurnal minimum value and stays at a relative low level during nighttime.
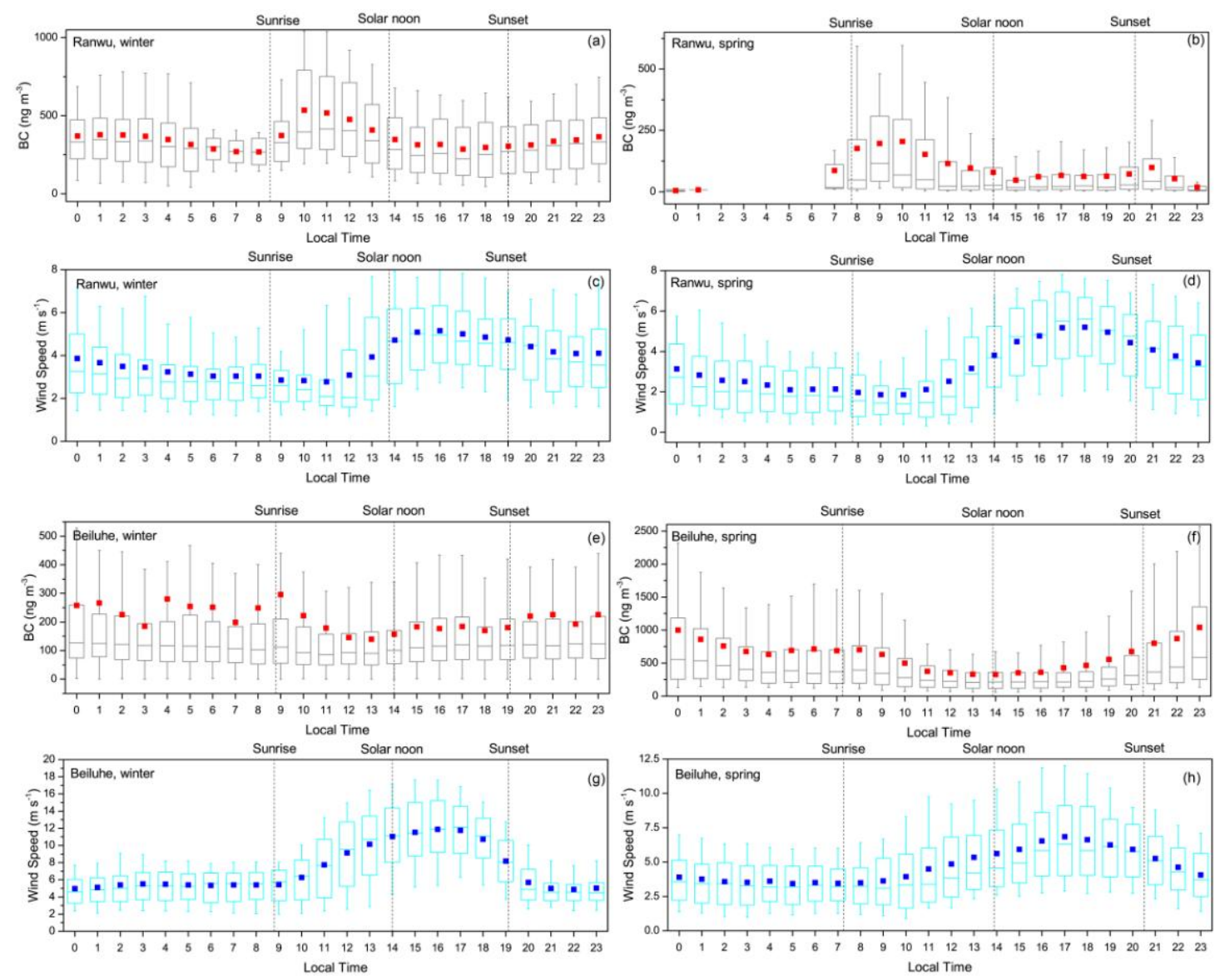
Figure 6 Diurnal variations of BC (in gray and red) and wind speed (in cyan and blue) at the Ranwu $(\mathrm{a}-\mathrm{d})$ and Beiluhe $(\mathrm{e}-\mathrm{h})$ sampling sites illustrated by box and whisker plots. The 25th, 50th, and 75th percentiles are marked with the box, and the 10th and 90th percentiles marked with whiskers. The colored square symbols denote mean values, and the vertical dashed lines mark the local time of sunrise, solar noon and sunset in each panel.

The diurnal variation of $\mathrm{BC}$ at Beiluhe is inconspicuous in winter. This is mainly attributed to the low BC concentration and high wind speed $\left(7.4 \mathrm{~m} \mathrm{~s}^{-1}\right.$ on average, Fig. 8). Although wind speed is significantly higher in the daytime, BC shows a moderately lower concentration $\left(185.1 \mathrm{ng} \mathrm{m}^{-3}\right.$ ) during the day than the night (233.4 $\mathrm{ng}$ $\mathrm{m}^{-3}$ ). However, the diurnal cycle is discernible in spring; the airborne BC shows low concentrations during the daytime (482.0 $\mathrm{ng} \mathrm{m}^{-3}$ on average) and high values during nighttime (804.8 $\mathrm{ng} \mathrm{m}^{-3}$, a 1.7 -fold increase). This variation is closely in line with atmospheric boundary layer dynamics (Fig. S4) and winds. The surface thermal convection driven by solar heating, along with the increased winds, facilitates the dispersion of aerosols including BC accumulated in the boundary layer, and consequently the $\mathrm{BC}$ shows low concentrations. When the boundary layer stabilizes and the wind speed decreases late in the day, BC starts to build up at night. This is similar to the wintertime nocturnal trend at Ranwu. The lack of a morning peak in BC concentrations at Beiluhe might be related to the influence of local emissions (e.g., residential heating, cooking), which we don't have observed evidence for. This warrants further study.

\subsection{BC potential sources}

Since the TP is a high-elevation and sparsely inhabited region, local emissions are rather weak compared to emissions from neighboring regions such as South Asia and East Asia. To identify source regions of air masses reaching the Ranwu and Beiluhe sampling sites, five-day backward air-mass trajectories are conducted using the NOAA HYSPLIT model and the NCEP/NCAR meteorological reanalysis dataset 
404 (Draxler and Rolph, 2003). The model is run every 6 hours for the whole sampling 405 period for each sampling site at $500 \mathrm{~m}$ above ground level. The cluster analysis 406 suggests air masses over the Ranwu sampling site are mostly from Bangladesh and 407 the Indo-Gangetic Plain for both winter (64.3\%) and spring (70.2\%) seasons (Fig. 7). 408 The remaining fraction of air masses in winter (35.7\%) is from the Middle East, 409 Afghanistan, Pakistan and northwest India and in spring largely from northwest India $410(26.3 \%)$. The small seasonal contrasts in contributions of air masses from Bangladesh 411 and the Indo-Gangetic Plain to the Ranwu sampling site are in line with the major 412 conclusion in Sect. 3.1, i.e., the monthly variation of regional precipitation in the 413 southeastern $\mathrm{TP}$ is the main cause of the seasonal dependence of airborne $\mathrm{BC}$ 414 concentration. For the Beiluhe sampling site, air masses are mostly from the south 415 slope of Himalayas (79.6\%) and the rest is from the Middle East and Central Asia 416 (20.4\%) in winter (Fig. 7). In spring, air masses are largely contributed by those from 417 the northwestern China (45.9\%), followed by Central Asia (32.4\%) and the south 418 slope of Himalayans (21.6\%). An increase in the contribution of air masses from 419 northwest China to the Beiluhe sampling site in spring is consistent with the 420 conclusion that in the hinterland the seasonal variation of sources associated with prevailing wind direction is very likely the dominant factor. 

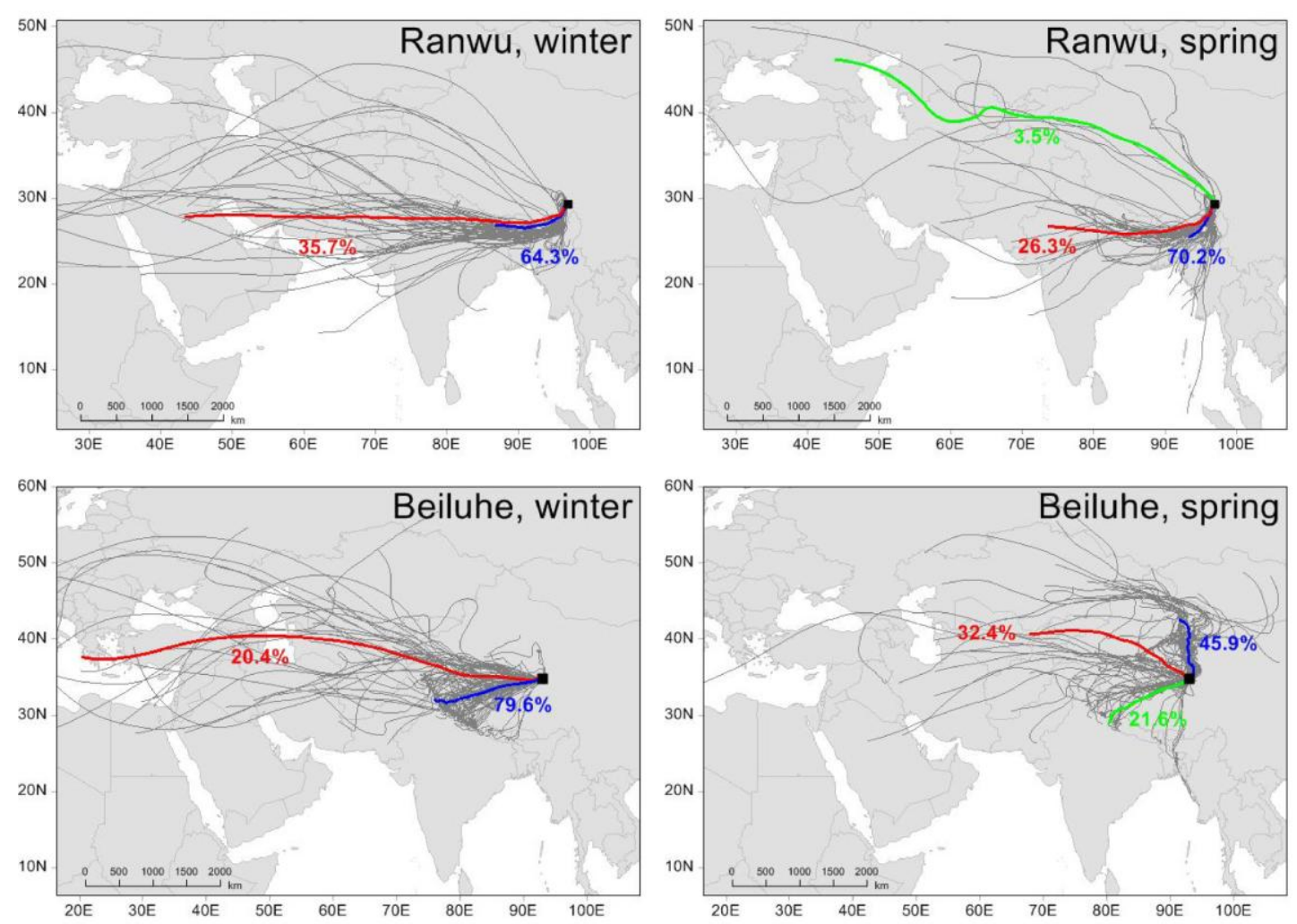

Figure 7. Five-day back trajectories of air masses at the Ranwu and Beiluhe sampling sites during the winter and spring.

To help understand the source of BC over the research areas, we use Cloud-Aerosol Lidar with Orthogonal Polarization (CALIOP) retrievals to identify the vertical distribution of aerosol subtypes. The nighttime profiles are used here as they have lower background noise than those in daytime (Marenco et al., 2014). We choose vertical profiles mainly according to the locations of sampling sites where the CALIPSO orbit closely passes by in the observation time period. The vertical profiles of aerosol subtypes in Figure 8 show that aerosol particles in the southeastern TP mostly consist of smoke and polluted dust, which are apparently related to human activities in South Asia, while aerosol particles in the TP hinterland largely consist of dust, especially, in spring when high load of dust is lifted from the Taklimakan Desert. Although the vertical profiles only represent a snapshot of vertical distribution of aerosol types, the demonstration of smoke and dust in the southern TP and the dominant dust in the northern TP, especially in spring, is consistent with our 
knowledge. The distributions of aerosol subtypes are consistent with the air mass back trajectory analysis we discussed above that BC at the Ranwu sampling site likely comes from anthropogenic emissions in south Asia and $\mathrm{BC}$ at the Beiluhe site is highly associated with transport from the arid region in the north.
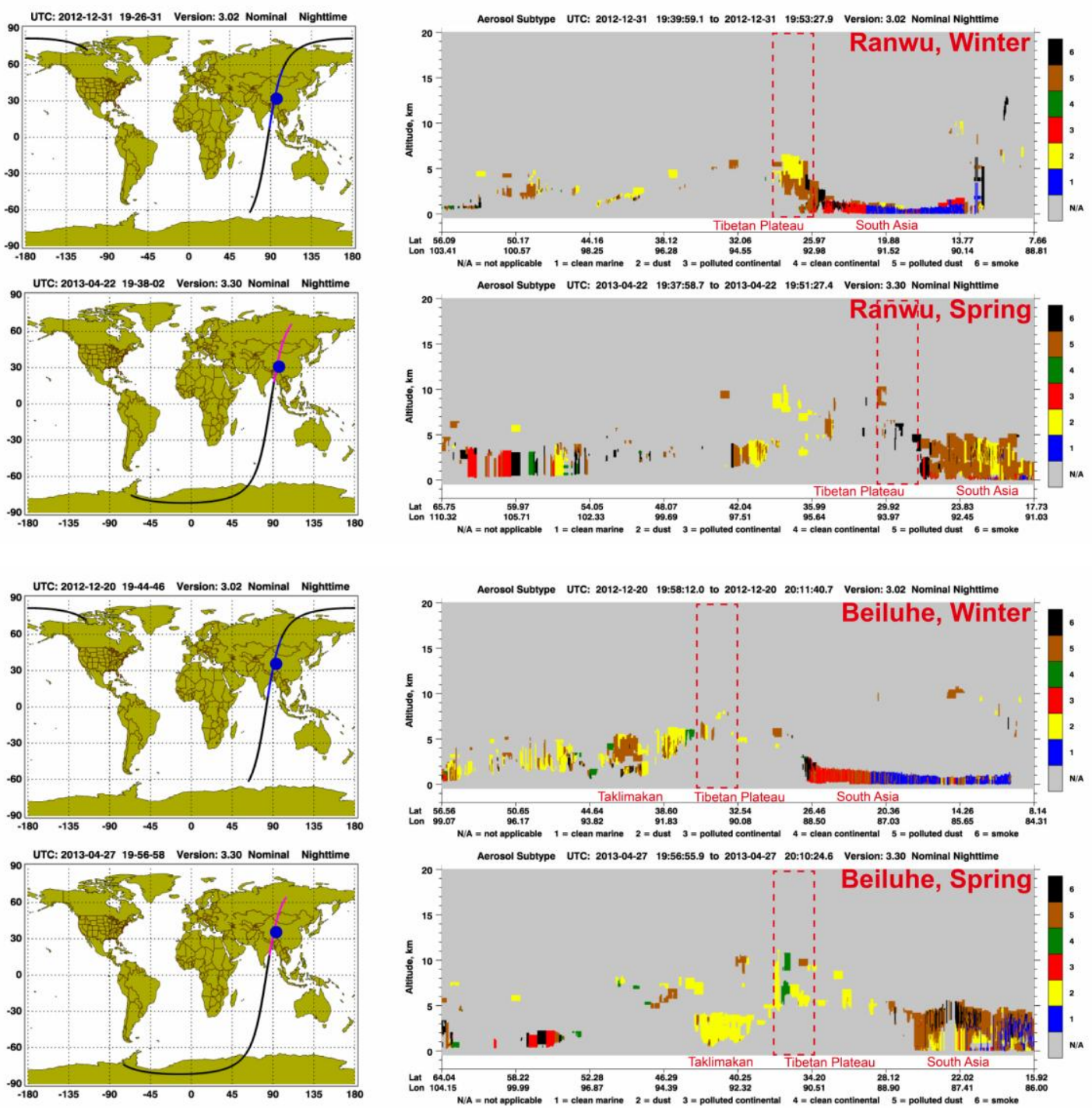

Figure 8 CALIPSO retrieved aerosol sub-type information at Ranwu and Beiluhe for winter and spring. The blue dot on the map in left panels marks the sampling sites. The red box (outlined with dashed lines) indicates the region where the sampling site locates.

\section{Conclusions}

Airborne BC concentrations at the Ranwu and Beiluhe sampling sites, located in 
the southeastern and central Tibetan Plateau, respectively, have been measured from November 2012 to June 2013. Seasonal variations of BC, dominant meteorological conditions, potential source regions as well as diurnal variations are investigated. Major conclusions are as follows:

1. The monthly mean $\mathrm{BC}$ concentrations show higher values in winter than in spring at the Ranwu sampling site, whereas it is opposite at Beiluhe. By examining the meteorological conditions at various scales, we found that the monthly variation of airborne $\mathrm{BC}$ over the southeastern $\mathrm{TP}$ was highly influenced by regional precipitation and over the hinterland by winds. Local precipitation at both sites showed little impact on the seasonal variation of airborne BC concentrations.

2. With the assistance of airmass backward trajectory analysis, potential BC source regions are identified. At Ranwu, BC was dominated by the air masses from the northeastern India and Bangladesh in both winter and spring, whereas at Beiluhe it was largely contributed by air masses from the south slope of Himalayas in winter, and from the arid region in the northwestern China in spring. According to CALIPSO aerosol subtypes, the high BC concentration over the southeastern TP in winter is most likely dominated by anthropogenic emissions in South Asia, whereas the high concentration in spring over the hindering TP region is likely associated with more efficient transport of $\mathrm{BC}$ from the arid region in the north.

3. Over the TP the seasonal variation of airborne $\mathrm{BC}$ concentration varies from the south to the north. In the southern TP, BC is largely contributed by emissions from South Asia and the seasonal variation is heavily influenced by the regional monsoon precipitation. As a result, the airborne $\mathrm{BC}$ concentrations showed a seasonal peak during winter and spring. In the northern TP, BC had high concentrations during spring and summer seasons.

4. Airborne $\mathrm{BC}$ concentrations at the Ranwu sampling site showed a significant diurnal pattern with a peak shortly after sunrise followed by a decrease before noon in both winter and spring. This is likely influenced by local human activities 
in the surrounding area and the diurnal variation of wind speed. At the Beiluhe sampling site, the diurnal variation of BC is different and less distinct.

\section{Acknowledgments}

This research was funded by the National Natural Science Foundation of China and the China National Funds for Distinguished Young Scientists, including 41430424, 41275186, 41101063, and 41125003. H. Wang acknowledges support from the US Department of Energy (DOE), Office of Science, Biological and Environmental Research. The Pacific Northwest National Laboratory (PNNL) is operated for DOE by Battelle Memorial Institute under contract DE-AC05-76RLO1830. We thank A. D. A. Hansen for his help in the analysis of Aethalometer data. The GIOVANNI, CALIPSO of NASA and HYSPLIT (ARL) of NOAA are also acknowledged for the data used in this research effort. 


\section{References}

Allen GA, Lawrence J, Koutrakis P. Field validation of a semi-continuous method for aerosol black carbon (aethalometer) and temporal patterns of summertime hourly black carbon measurements in southwestern PA. Atmos Environ 1999; 33(5): 817-823.

Babu SS, Chaubey JP, Krishna Moorthy K, Gogoi MM, Kompalli SK, Sreekanth V, Bagare S, Bhatt BC, Gaur VK, Prabhu TP. High altitude $(\sim 4520 \mathrm{~m}$ amsl $)$ measurements of black carbon aerosols over western trans - Himalayas: Seasonal heterogeneity and source apportionment. J Geophys Res Atmos (1984-2012) 2011; 116, doi:10.1029/2011JD016722.

Beegum SN, Moorthy KK, Babu SS, Satheesh SK, Vinoj V, Badarinath KVS, Safai PD, Devara PCS, Singh S, Vinod, Dumka UC, Pant P. Spatial distribution of aerosol black carbon over India during pre-monsoon season. Atmos Environ 2009; 43(5): 1071-1078, doi:10.1016/j.atmosenv.2008.11.042.

Cao J, Tie X, Xu B, Zhao Z, Zhu C, Li G, Liu S. Measuring and modeling black carbon (BC) contamination in the SE Tibetan Plateau. J Atmos Chem 2010; 67(1): 45-60.

Cao J, Xu B, He J, Liu X, Han Y, Wang G, Zhu C. Concentrations, seasonal variations, and transport of carbonaceous aerosols at a remote Mountainous region in western China. Atmos Environ 2009; 43: 4444-4452, doi:10.1016/j.atmosenv.2009.06.023, 2009.

Chung CE, Ramanathan V, Decremer D. Observationally constrained estimates of carbonaceous aerosol radiative forcing. Proc Natl Acad Sci USA 2012; 109(29): 11624-11629.

Cong Z, Kawamura K, Kang S, Fu P. Penetration of biomass-burning emissions from South Asia through the Himalayas: new insights from atmospheric organic acids. Sci Rep UK 2015; 5, doi:10.1038/srep09580.

Draxler RR, Rolph GD. HYSPLIT (HYbrid Single-Particle Lagrangian Integrated Trajectory) Model. NOAA Air Resources Laboratory, Silver Spring, MD. 2003. Available online: http://www.arl.noaa.gov/ready/hysplit4.html.

Flanner MG, Zender CS, Randerson JT, Rasch PJ. 2007. Present-day climate forcing and response from black carbon in snow. J Geophys Res Atmos (1984-2012) 2007; 112 (D11). http://dx.doi.org/10.1029/2006JD008003.

Gao R, Niu S, Zhang H, Guo J, Meng D, Ma J, Feng J, Zhang Y. A comparative study on black carbon aerosol observations in regions of Beijing and Lhasa in 2006. In Optical Engineering Applications 2007 Sep 13 (pp. 66791T-66791T). International Society for Optics and Photonics.

Hadley OL, Kirchstetter TW. Black-carbon reduction of snow albedo. Nat Clim Change 2012; 2: 437-440.

Hansen ADA, Rosen H, Novakov T. Real-time measurement of the absorption coefficient of aerosol particles. Appl Optics 1982; 21(17), 3060-3062. 
Hansen ADA. Aethalometer-User Manual, Magee Scientific Company, California, USA, 210pp., 2005.

Hansen J, Nazarenko L. Soot climate forcing via snow and ice albedos. Proc Natl Acad Sci USA 2004; 101: 423-428, doi:10.1073/pnas.2237157100, 2004.

Hyvärinen AP, Lihavainen H, Komppula M, Sharma VP, Kerminen VM, Panwar TS, Viisanen Y. (2009). Continuous measurements of oallptical properties of atmospheric aerosols in Mukteshwar, northern India. J Geophys Res Atmos (1984-2012) 2009; 114(D8).

Jeong CH, Hopke PK, Kim E, Lee DW. The comparison between thermal-optical transmittance elemental carbon and Aethalometer black carbon measured at multiple monitoring sites. Atmos Environ 2004; 38(31): 5193-5204.

Ji Z, Kang S, Zhang Q, Cong Z, Chen P, Sillanpää M. Investigation of mineral aerosols radiative effects over High Mountain Asia in 1990-2009 using a regional climate model. Atmos Res 2016; 178: 484-96.

Kopacz M, Mauzerall DL, Wang J, Leibensperger EM, Henze DK, Singh K. Origin and radiative forcing of black carbon transported to the Himalayas and Tibetan Plateau. Atmos Chem Phys 2011; 11: 2837-2852, doi:10.5194/acp-11-2837-2011, 2011.

Lawrence PJ, Chase TN. Representing a new MODIS consistent land surface in the community land model (CLM 3.0). J Geophys Res Atmos (1984-2012) 2007; 112, G01023. http://dx.doi.org/10. 1029/2006JG000168.

Li J, Huang K, Wang Q, Lin Y, Xue F, Huang J, Fu SJ, Zhuang G. Characteristics and source of black carbon aerosol over Taklimakan Desert. Sci China Chem 2010; 53(5):1202-1209.

Lu Z, Streets DG, Zhang Q, Wang S. A novel backtrajectory analysis of the origin of black carbon transported to the Himalayas and Tibetan Plateau during 1996-2010, Geophys Res Lett 2012; 39, L01809, doi:10.1029/2011GL049903.

Lüthi ZL, Škerlak B, Kim S-W, Lauer A, Mues A, Rupakheti M, Kang S. Atmospheric brown clouds reach the Tibetan Plateau by crossing the Himalayas. Atmos Chem Phys 2015; 15 : 6007-6021, doi:10.5194/acp-15-6007-2015.

Marenco F, Amiridis V, Marinou E, Tsekeri A, Pelon J. Airborne verification of CALIPSO products over the Amazon: a case study of daytime observations in a complex atmospheric scene. Atmos Chem Phys 2014; 14(21):11871-11881.

Ming J, Xiao C, Cachier H, Qin D, Qin X, Li Z, Pu J. 2009: Black Carbon (BC) in the snow of glaciers in west China and its potential effects on albedos. Atmos Res 2009; 92(1): 114-123, doi:10.1016/j.atmosres.2008.09.007.

Ming J, Xiao C, Sun J, Kang S, Bonasoni P. Carbonaceous particles in the atmosphere and precipitation of the Nam Co region, central Tibet. J Environ Sci 2010; 22(11):1748-56.

Nair VS, Babu SS, Moorthy KK, Sharma AK, Marinoni A. Black carbon aerosols over the Himalayas: direct and surface albedo forcing. Tellus B 2013; 65, 19738, http://dx.doi.org/10.3402/tellusb.v65i0.19738. 
Pathak, B., Kalita G., Bhuyan K., Bhuyan PK, Moorthy KK. Aerosol temporal characteristics and its impact on shortwave radiative forcing at a location in the northeast of India. J Geophys Res Atmos 2010; 115(D19), doi:10.1029/2009JD013462.

Qian Y, Flanner MG, Leung LR, Wang W. Sensitivity studies on the impacts of Tibetan Plateau snowpack pollution on the Asian hydrological cycle and monsoon climate. Atmos Chem Phys 2010; 11: 1929-1948.

QianY., Yasunari TJ, Doherty SJ, Flanner MG, Lau WKM, Ming J, Wang H, Wang M., Warren SG, Zhang R. (2015). Light-absorbing particles in snow and ice: Measurement and modeling of climatic and hydrological impact. Adv Atmos Sci 2015; 32(1): 64-91, doi:10.1007/s00376-014-0010-0.

Ramanathan V, Carmichael G. Global and regional climate changes due to black carbon. Nat Geosci 2008; 1: 221-227.

Ramanathan V, Li F, Ramana MV, Praveen PS, Kim D, Corrigan CE, Nguyen H, Stone EA, Schauer JJ, Carmichael GR, Adhikary B. Atmospheric brown clouds: Hemispherical and regional variations in long-range transport, absorption, and radiative forcing. J Geophys Res Atmos (1984-2012) 2007a; 112, D22S21, doi:10.1029/2006JD008124.

Ramanathan V, Ramana MV, Roberts G, Kim D, Corrigan C, Chung C, Winker D. Warming trends in Asia amplified by brown cloud solar absorption. Nature 2007b; 448: 575-578, doi:10.1038/nature06019.

Richardson HD, Reynolds JM. An overview of glacial hazards in the Himalayas. Quat Int 2000; 65/66: 31-47.

Tang J, Wen Y, Zhou L, Qi D, Zheng M, Trivett N, Wallgren E. Observational study of black carbon in clean air area of western China. Q J Appl Meteorol 1999; 10(2): 160-170, in Chinese.

Tiwari S, Srivastava AK, Bisht DS, Bano T, Singh S, Behura S, Srivastava MK, Chate DM, Padmanabhamurty B. (2009). Black carbon and chemical characteristics of PM10 and PM2. 5 at an urban site of North India. J Atmos Chem 2009; 62(3): 193-209, doi:10.1007/s10874-010-9148-z.

USDA, 1999. Soil Taxonomy, a Basic System of Soil Classification for Making and Interpreting Soil Surveys. US Government Printing Office, Washington, USA (869 pp.).

Valipour M, Eslamian S. Analysis of potential evapotranspiration using 11 modified temperature-based models. Int J Hydrol Sci Tech 2015; 4(3): 192-207, doi:http://dx.doi.org/10.1504/IJHST.2014.067733.

Valipour, M. Comparative Evaluation of Radiation-Based Methods for Estimation of Potential Evapotranspiration. J Hydrol Eng 2014; 20(5): 04014068, doi: 10.1061/(ASCE)HE.1943-5584.0001066.

Valipour, M. Temperature analysis of reference evapotranspiration models. Meteorol Appl 2015; 22(3): 385-394, doi:10.1002/met.1465. 
600

601

602

603

604

605

606

607

608

609

610

611

612

613

614

615

616

617

618

619

620

621

622

623

624

625

626

627

628

629

630

631

632

633

634

635

Wang M, Xu B, Cao J, Tie X, Wang H, Zhang R, Qian Y, Rasch PJ, Zhao S, Wu G, Zhao H, Joswiak DR, Li J, Xie Y. 2015b. Carbonaceous aerosols recorded in a southeastern Tibetan glacier: analysis of temporal variations and model estimates of sources and radiative forcing. Atmos Chem Phys 2015a; 15: 1191-1204. http://dx.doi.org/10.5194/acp-15-1191-2015.

Wang M, Xu B, Kaspari S, Gleixner G, Schwab VF, Zhao H, Wang H, Yao P. Variation of Black Carbon from a Muztagata Ice Core during 1868-2000 and its Biomass Contribution. Atmos Environ 2015b; 115(2015): 79-88. http://dx.doi.org/10.1016/j.atmosenv.2015.05.034.

Warren SG, Wiscombe WJ. A model for the spectral albedo of snow. II: Snow containing atmospheric aerosols. J Atmos Sci 1980; 37(12): 2734-2745.

Wu G, Xu B, Zhang C, Gao S. Atmospheric dust aerosols over the Eastern Pamirs: major element concentrations and composition. Environ Earth Sci 2010; 61(6): 1227-1237.

Wu G, Yao T, Xu B, Tian L, Li Z, Duan K. Seasonal variations of dust record in the Muztagata ice cores. Chinese Sci Bull 2008; 53(16): 2506-2512.

Xu B, Cao J, Hansen J, Yao T, Joswiak DR, Wang N, Wu GJ, Wang M, Zhao HB, Yang W, Liu X, He J. 2009a. Black soot and the survival of Tibetan glaciers. Proc Natl Acad Sci USA 2009a; 106(52): 22114-22118, doi:10.1073/pnas.0910444106.

Xu B, Wang M, Joswiak DR, Cao J, Yao T, Wu G, Yang W, Zhao H. Deposition of anthropogenic aerosols in a southeastern Tibetan glacier. J Geophys Res 2009b; 114, D17209, doi:10.1029/2008JD011510.

Yang S, Xu B, Cao J, Zender CS, Wang M. Climate effect of black carbon aerosol in a Tibetan Plateau Glacier. Atmos Environ 2015; 111: 71-78, doi:10.1016/j.atmosenv.2015.03.016.

Yao T, Masson - Delmotte V, Gao J, Yu W, Yang X, Risi C, Sturm C, Werner M, Zhao H, He Y, Ren W. A review of climatic controls on $\delta 18 \mathrm{O}$ in precipitation over the Tibetan Plateau: Observations and simulations. Rev Geophys 2013; 51(4): 525-548.

Yao T, Wand Y, Liu S, Pu J, Shen Y, Lu A. Recent glacial retreat in High Asia in China and its impact on water resource in Northwest China. Sci China, Ser D 2004; 47(12): 1065-1075.

Ye D, Gao Y. Meteorology of the Tibetan Plateau. Science Press, Beijing, pp. 49-61, 1979.

Zhang R, Wang H, Qian Y, Rasch PJ, Easter RC, Ma PL, Singh B, Huang J, Fu Q. Quantifying sources, transport, deposition and radiative forcing of black carbon over the Himalayas and Tibetan Plateau. Atmos Chem Phys 2015; 15(11): 6205-6223.

Zhao S, Ming J, Xiao C, Sun W, Qin X. A preliminary study on measurements of black carbon in the atmosphere of northwest Qilian Shan. J Environ Sci 2012; 24(1): 152-159.

Zhao Z, Cao J, Shen Z, Xu B, Zhu C, Chen LW, Su X, Liu S, Han Y, Wang G, Ho K. Aerosol particles at a high-altitude site on the Southeast Tibetan Plateau, China: implications for pollution transport from South Asia. J Geophys Res Atmos 2013; 118: 11,360-11,375, doi:10.1002/jgrd.50599. 